\title{
PERSEPSI MAHASISWA PPLK \\ PROGRAM STUDI PENDIDIKAN BAHASA INGGRIS FBS UNP \\ TERHADAP TUGAS DAN TANGGUNG JAWAB GURU PAMONG
}

\author{
Sitti Fatimah \\ FBS Universitas Negeri Padang
}

\begin{abstract}
This article is written based on the research aiming at describing the duties and responsibilities of supervising teachers during the conduction of student-teaching program in the period of January-June 2010 by English department students. The data was taken from the questionnaires given to the student-teachers whose perceptions about the supervising teachers' duties and responsibilities. Generally, the questionnaires asked the sample about the performing of duties and responsibilities by supervising teachers in three periods: observation, guided teaching and independent teaching period. Based on the data it is found that although in the third (independent teaching) period the supervising teachers performed their duties and responsibilities well, both in the first (observation) and second (guided teaching) period the supervising teachers did not perform their duties and responsibilities as they should have been.
\end{abstract}

Key words: student-teachers, supervising teachers, duties and responsibilities, observation, guided teaching and independent teaching period.

\section{A. PENDAhULUAN}

Keterampilan mengajar (teaching skill) adalah salah satu keahlian yang harus dimiliki oleh seorang guru sebagai tenaga pengajar yang profesional. Karena "mengajar tidak hanya sekadar menyampaikan materi pelajaran tapi suatu kegiatan yang didasarkan pada konsep dan ilmu pengetahuan yang spesifik yang dapat dipertanggungjawabkan secara ilmiah (Sanjaya, 2006, p.16)”. Selanjutnya Sanjaya memaparkan tiga macam kompetensi yang harus dimiliki oleh seorang guru profesional. Yang pertama adalah kompetensi pribadi (personal competencies), kemudian kompetensi profesional (professional competencies) dan kompetensi sosial kemasyarakatan (social competencies). Dengan sejumlah persyaratan yang harus dimiliki oleh seseorang untuk dapat berprofesi sebagai guru, maka pemerolehan keterampilan mengajar sebaiknya dilakukan melalui pembelajaran di institusi pendidikan formal seperti di Lembaga Pendidikan Tenaga Kependidikan (LPTK).

Untuk membekali mahasiswa dengan keterampilan mengajar seperti dijelaskan di atas, salah satu mata kuliah di dalam kurikulum Program Studi (Prodi) LPTK adalah sebuah pembelajaran di mana setiap mahasiswa yang mengambil mata kuliah tersebut mempraktekkan ilmu dan keterampilan yang diperoleh di dalam kelas. Pembelajaran dalam mata kuliah ini juga memungkinkan mahasiswa untuk mulai merasakan dan mengetahui bagaimana sebuah keterampilan mengajar sangat diperlukan untuk keberhasilan siswa didik. Mata kuliah yang berbobot 6 (enam) sks ini disebut dengan Praktek Lapangan (PL), kemudian namanya disempurnakan menjadi Program Pengalaman Lapangan Kependidikan (PPLK). PPLK diikuti oleh 
mahasiswa yang telah menabung minimal 110 sks untuk program S1 dan biasanya diambil selama satu semester penuh pada semester ke-7.

Pelaksanaan PPLK dapat dibagai menjadi 3 (tiga) kegiatan. Kegiatan pertama yang berlangsung selama 3 (tiga) minggu adalah kegiatan observasi, dimana mahasiswa berada 2 (dua) minggu di sekolah latihan dan 1 (satu) minggu di kampus. Selama masa observasi ini, interaksi mahasiswa dengan guru pamong mulai dilakukan. Kegiatan kedua adalah Latihan Mengajar Terbimbing (LMT) selama 4 (empat) kali yang dipantau oleh guru pamong dan dibimbing oleh dosen pembimbing. Kemudian dilanjutkan dengan Latihan Mengajar Mandiri (LMM) yang dipantau minimal 3 kali oleh guru pamong.

Disamping kegiatan pembelajaran pengajaran di atas, mahasiswa yang mengikuti PPLK juga diwajibkan melakukan kegiatan kependidikan lainnya yang mendukung proses pembelajaran/pelayanan. Diantaranya adalah memberi bimbingan kepada siswa yang menemui kesulitan, mengerjakan tugas administrasi kelas dan sekolah, merencanakan dan melaksanakan kegiatan ekstra-kurikuler, melibatkan diri secara aktif dalam kegiatan sekolah dan sebagainya.

Secara akademis guru pamong memiliki tugas dan tanggungjawab yang cukup berpengaruh pada kelangsungan pelaksanaan PPLK. Seperti tertuang dalam buku pedoman PPLK yang diterbitkan UPPL UNP tahun 2009, tugas dan tanggungjawab guru pamong dimulai sejak pra-program. Siswa yang telah diserahkan secara simbolik oleh dosen pembimbingnya kepada masing-masing guru pamong, akan menjadi tugas dan tanggungjawab guru pamong dalam membimbing dan melatih siswa tersebut selama mereka melaksanakan PPLK di sekolah latihan bersangkutan. Untuk satu semester ke depan guru pamong akan membimbing mahasiswa PPLK, seperti menyediakan dan mempersiapkan kelas untuk mahasiswa yang akan melakukan praktek mengajar.

Akan tetapi pada kenyataannya tugas dan tanggungjawab yang seharusnya dilaksanakan dengan baik oleh guru pamong tidak sesuai dengan apa yang telah dirambu-rambukan di dalam buku pedoman PPLK yang diterbitkan oleh UPPL UNP. Dari kenyataan di lapangan yang dialami langsung oleh beberapa mahasiswa PPLK dari Prodi Pendidikan Bahasa Inggris, pada masa observasi dimana mahasiswa seharusnya hanya melakukan observasi tentang semua kegiatan pembelajaran di dalam kelas, sudah diwajibkan oleh guru pamong untuk mengajar sebagaimana layaknya seorang guru yang sudah berpengalaman. Pada periode Latihan Mengajar Terbimbing (LMT) yang terdiri dari 4 (empat) kali latihan, banyak guru pamong yang tidak memberikan bantuan atau membimbing mahasiswa PPLK tersebut sebagaimana seharusnya. Pada proses latihan pengajaran oleh mahasiswa PPLK di periode ini guru pamong sering sekali tidak memonitor. Sementara pada Latihan Mengajar Mandiri (LMM) para guru pamong tersebut benar-benar membiarkan mahasiswa PPLK tersebut mengajar tanpa adanya pembimbingan sama sekali. Padahal menurut buku pedoman PPLK mereka masih perlu dibimbing.

Berdasarkan fakta dan asumsi awal inilah, penelitian ini kemudian dilakukan untuk mengetahui fakta sesungguhnya. Secara lebih detil penelitan ini melihat sejauh mana guru pamong melaksanakan tugas dan tanggungjawabnya selama 3 (tiga) periode yang disebutkan di atas, yaitu observasi, latihan mengajar terbimbing dan latihan mengajar mandiri.

Karena penunjukkan utamanya dilakukan oleh LPTK yang mengirim mahasiswa PPLK dan sekaligus pencetak guru-guru, pengaturan tentang apa-apa yang harus dilakukan oleh guru pamong ditetapkan oleh LPTK. Tugas dan tanggung jawab tersebut diatur dalam buku Pedoman PPLK (2009) sebagaimana berikut: (1) Menjelaskan/mensosialisasaikan kepada 
mahasiswa tentang tugas-tugas seorang guru. (2) Memperkenalkan mahasiswa kepada siswa-siswa di sekolah latihan, (3) Memberi penjelasan kepada mahasiswa tentang masalah-masalah rutin dalam kelas, peraturan-peraturan dalam kelas, dan sebagainya, (4) Memberikan penjelasan kepada mahasiswa tentang alat-alat pengajaran, media pendidikan, sumbersumber belajar yang tersedia di sekolah serta pemakaian atau penggunaan, (5) Menyediakan dan mempersiapkan kelas untuk mahasiswa yang akan melakukan praktek mengajar (jumlah jam mengajar untuk setiap mahasiswa maksimum 6 (enam) kali pertemuan/tatap muka setiap minggu. Jika jam mengajar di sekolah latihan termasuk yang ditentukan kurang dari jam maksimum, guru pamong dibolehkan membawa mahasiswa ke sekolah yang sederajat selama hal tersebut tidak melebihi pertemuan maksimum minggun yang ditentukan, (6) Memberikan bimbingan kepada mahasiswa dalam perencanaan dan pelaksanaan praktek mengajar, (7) Mendiskusikan masalahmasalah yang ditemui dalam pembimbingan, dimana perlu bersama pimpinan pamong untuk dicarikan jalan keluarnya, (8) Mencatat kemajuan latihan mahasiswa di dalam Buku Evaluasi, (9) Menguji dan menilai kegiatan mengajar dan kependidikan lainnya yang telah dilaksanakan mahasiswa serta mencatat hasilnya pada Buku Evaluasi, dan (10) Menyerahkan Buku Evaluasi mahasiswa kepada dosen pembimbing.

Selain tugas dan tanggung jawab di atas seorang guru pamong juga memiliki tugas pokok dan fungsi sehubungan dengan pelaksanaan pamongannya. Tugas pokok dan fungsi tersebut antara lain: (1) Membimbing sikap dan prilaku mahasiswa menjadi guru profesional, (2) Membimbing mahasiswa menyusun persiapan pembelajaran (RPP), (3) Membimbing mahasiswa membuat media pembelajaran, (4) Membimbing mahasiswa dalam kegiatan pembelajaran di kelas, (5) Membimbing mahasiswa dalam merencanakan dan melaksanakan penelitian tindakan kelas, (6) Membimbing mahasiswa dalam merencanakan dan melaksanakan kegiatan non-teaching, (7) Membimbing mahasiswa dalam kegiatan sosial sesama mahasiswa PL, majlis guru, siswa dan tenaga kependidikan lainnya di sekolah, (8) Memberikan nilai kegiatan observasi, pembeljaran terbimbing mandiri, dan latihan akhir pembelajaran, (9) Meningkatkan konsultasi dengan dosen pembimbing dalam meningkatkan kualitas kemampuan mahasiswa sebagai guru, dan (10) Memberi sanksi pada mahasiswa jika melanggar aturan sekolah dan bersikap dan berprilaku tidak baik.

\section{B. METODE PENELITIAN}

Sesuai dengan masalah dan tujuan penelitian ini yaitu untuk menemukan dan menjelaskan seberapa jauh tugas dan tanggungjawab yang dilakukan guru pamong dalam pelaksanaan PPLK berdasarkan persepsi mahasiswa Prodi Pendidikan Bahasa Inggris Jurusan Bahasa dan Sastra Inggris FBSS UNP, serta dikaitkan dengan pelaksanaan penelitian, disain penelitian yang sesuai adalah deskriptif-kualitatif. Penelitian ini berupaya menemukan dan menjelaskan apakah guru pamong telah melaksanakan tugas dan tanggung jawab sesuai dengan pedoman pelaksanaan PPLK yang diterbitkan oleh UPPL UNP. Konsep ini sesuai dengan apa yang telah disarankan oleh Bogdan dan Biklen dalam Alwasilah (2006, p. 26). Metode penelitian ini juga disebut penelitian survey karena penelitian ini menggambarkan opini seseorang (respondent) terhadap sebuah masalah (issue) dengan memberikan pertanyaan dalam sebuah angket, sebagaimana yang dijelaskan oleh Gay (2009, p. 177).

Berdasarkan rancangan penelitian tersebut, data penelitian yang diperoleh sebelum dideskripsikan secara kualitatif, terlebih dahulu dihitung persentasenya. Hasil persentase ini dipakai sebagai dasar pengkualifikasian data. Data penelitian kualitatif yang bersifat deskriptif memiliki latar yang bersifat alami karena data tersebut diperoleh dalam proses pengisian 
angket (questionnaires) yang wajar, bukan manipulasi. Selain itu, penelitian ini menitikberatkan pada pengumpulan dan analisa data tentang respon atau jawaban yang diberikan mahasiswa PPLK terhadap tugas dan tanggungjawab guru pamong mereka selama pelaksanaan PPLK berlangsung.

Sumber data penelitian ini adalah seluruh mahasiswa Prodi Pendidikan Bahasa Inggris, Jurusan Bahasa dan Sastra Inggris, Universitas Negeri Padang yang mengambil mata kuliah PPLK pada periode Januari-Juni 2010. Ada 103 mahasiswa yang tersebar pada 90 sekolah latihan di hampir seluruh wilayah Sumatera Barat. Semua mahasiswa ini diberikan sebuah angket yang memuat 19 pertanyaan sehubungan dengan tugas dan tanggungjawab guru pamong selama masa observasi, latihan mengajar terbimbing dan latihan mengajar mandiri.

Respon terhadap angket ini kemudian dihitung persentasenya dengan menggunakan rumus sebagai berikut:

$$
\begin{aligned}
& \mathrm{P}=\underline{\mathrm{F}} \times 100 \% \\
& \mathrm{P}=\text { persentasi jawaban } \\
& \mathrm{F}=\text { frekwensi } \\
& \mathrm{N}=\text { jumlah total respondents }
\end{aligned}
$$

Skala, persentase dan deskripsi angket yang digunakan adalah sebagai berikut:

\begin{tabular}{|c|c|c|}
\hline Skala & Persentase & Deskripsi \\
\hline Selalu (SL) & $100 \%-81 \%$ & Sangat baik \\
Sering (SR) & $61 \%-80 \%$ & Baik \\
Jarang (JR) & $41 \%-60 \%$ & Buruk \\
Tidak Pernah (TP) & $0 \%-40 \%$ & Sangat buruk \\
\hline
\end{tabular}

Respon yang diperoleh dengan menggunakan skala dan persentase ini kemudian digambarkan dalam bentuk katakata.

\section{PENYAJIAN DATA DAN PEMBAHASAN}

Data tentang persepsi mahasiswa PPLK tentang tugas dan tanggungjawab guru pamong dibagi menjadi tiga indikator yang berdasarkan kepada tiga periode pelaksanaan PPLK selama semester
Januari-Juni 2010 yaitu selama periode observasi, latihan mengajar terbimbing dan latihan mengajar mandiri. Ketiga indikator tersebut dibagi menjadi 19 pertanyaan. Jawaban dari setiap pertanyaan dianalisa dalam bentuk persentase sebagaimana tercantum dalam tabel 2 berikut. Data yang terdapat dalam Tabel 2 kemudian dikonversikan ke dalam bentuk deskripsi untuk menganalisa persepsi mahasiswa tentang tugas dan tanggungjawab guru pamong (lihat Tabel 3).

Tabel 2. Persentase Tiap Pertanyaan (\%)

\begin{tabular}{|l|l|c|c|c|c|}
\hline \multicolumn{1}{|c|}{ Pertanyaan } & SL & SR & JR & TP \\
\hline & $\begin{array}{l}\text { Selama masa observasi } \\
\text { 1. Apakah guru pamong menjelaskan kepada anda } \\
\text { tentang bagaimana sikap dan perilaku anda } \\
\quad \begin{array}{l}\text { seharusnya sebagai calon guru profesional? } \\
\text { 2. Apakah guru pamong membantu anda dalam } \\
\text { merencanakan kegiatan non-teaching yang akan } \\
\text { anda lakukan? }\end{array}\end{array}$ & 83.5 & 0 & 0 & 16.5 \\
$\begin{array}{l}\text { 3. Apakah guru pamong membimbing anda } \\
\text { bersosialisasi dengan mahasiswa PL lainnya? } \\
\text { 4pakah guru pamong membimbing anda } \\
\text { bersosialisasi dengan para guru lainnya di sekolah? }\end{array}$ & 0 & 68.9 & 0 & 37.9 & 62.1 \\
\hline
\end{tabular}




\begin{tabular}{|c|c|c|c|c|}
\hline $\begin{array}{l}\text { 5. Apakah guru pamong membimbing anda } \\
\text { bersosialisasi dengan para siswa di sekolah? } \\
\text { 6. Apakah guru pamong membimbing anda } \\
\text { bersosialisasi dengan para pegawai sekolah lainnya? } \\
\text { 7. Apakah guru pamong menilai kegiatan observasi } \\
\text { yang anda lakukan di awal PL? }\end{array}$ & $\begin{array}{l}0 \\
0 \\
0\end{array}$ & $\begin{array}{l}0 \\
0\end{array}$ & $\begin{array}{l}47.6 \\
43.7\end{array}$ & 29.1 \\
\hline $\begin{array}{l}\text { Selama masa latihan terbimbing (LMT) } \\
\text { 8. Apakah guru pamong membantu anda dalam } \\
\text { mempersiapkan RPP? } \\
\text { 9. Apakah guru pamong membantu anda dalam } \\
\text { mempersiapkan media pembelajaran? } \\
\text { 10. Setelah anda mengajar, apakah ada tindak lanjut dari } \\
\text { guru pamong tentang media anda? } \\
\text { 11. Apakah guru pamong membantu anda selama proses } \\
\text { belajar mengajar di dalam kelas? } \\
\text { 12. Apakah guru pamong membantu anda dalam } \\
\text { merencanakan dan menjalankan PTK? } \\
\text { 13. Apakah guru pamong membantu anda dalam } \\
\text { melaksanakan kegiatan non-teaching? } \\
\text { 14. Apakah guru pamong menilai pembelajaran } \\
\text { terbimbing anda selama PL? } \\
\text { 15. Apakah guru pamong pernah berdiskusi dengan } \\
\text { dosen pembimbing anda? } \\
\text { 16. Apakah guru pamong pernah memberi sanksi } \\
\text { kepada anda ketika anda melanggar aturan sekolah? } \\
\text { 17. Apakah guru pamong pernah memberi sanksi } \\
\text { kepada anda ketika anda bersikap dan berprilaku } \\
\text { tidak baik? }\end{array}$ & $\begin{array}{c}0 \\
0 \\
92,3 \\
0 \\
0 \\
0 \\
91,3 \\
0 \\
0,9 \\
1,9\end{array}$ & $\begin{array}{c}79,7 \\
0 \\
0 \\
0 \\
0 \\
0 \\
0 \\
0 \\
0 \\
0\end{array}$ & $\begin{array}{c}0 \\
32,1 \\
0 \\
25,3 \\
0 \\
29,2 \\
0 \\
38,9 \\
0 \\
0\end{array}$ & $\begin{array}{r}20,3 \\
0 \\
7,7 \\
0 \\
14,6 \\
0 \\
8,7 \\
0 \\
99,1 \\
98.1\end{array}$ \\
\hline $\begin{array}{l}\text { Selama masa latihan mandiri (LMM) } \\
\text { 18. Apakah guru pamong menilai pembelajaran mandiri } \\
\text { anda selama PL? } \\
\text { 19. Apakah guru pamong menilai anda dalam latihan } \\
\text { akhir pembelajaran? }\end{array}$ & $\begin{array}{l}0 \\
0\end{array}$ & $\begin{array}{l}81.6 \\
82.6\end{array}$ & $\begin{array}{l}0 \\
0\end{array}$ & $\begin{array}{l}18.4 \\
17.4\end{array}$ \\
\hline
\end{tabular}

Tabel 3. Persepsi Mahasiswa PPLK

\begin{tabular}{|c|c|c|c|c|}
\hline Pertanyaan & SL & SR & JR & $\mathbf{T P}$ \\
\hline $\begin{array}{l}\text { Selama masa observasi } \\
\text { 1. Apakah guru pamong menjelaskan kepada anda } \\
\text { tentang bagaimana sikap dan perilaku anda } \\
\text { seharusnya sebagai calon guru profesional? } \\
\text { 2. Apakah guru pamong membantu anda dalam } \\
\text { merencanakan kegiatan non-teaching yang akan } \\
\text { anda lakukan? } \\
\text { 3. Apakah guru pamong membimbing anda } \\
\text { bersosialisasi dengan mahasiswa PL lainnya? } \\
\text { 4. Apakah guru pamong membimbing anda } \\
\text { bersosialisasi dengan para guru lainnya di sekolah? } \\
\text { 5. Apakah guru pamong membimbing anda } \\
\text { bersosialisasi dengan para siswa di sekolah? } \\
\text { 6. Apakah guru pamong membimbing anda }\end{array}$ & V & V & $\mathrm{V}$ & \\
\hline
\end{tabular}




\begin{tabular}{|c|c|c|c|c|}
\hline $\begin{array}{l}\text { bersosialisasi dengan para pegawai sekolah lainnya? } \\
\text { 7. Apakah guru pamong menilai kegiatan observasi } \\
\text { yang anda lakukan di awal PL? }\end{array}$ & & & $\mathrm{V}$ & \\
\hline $\begin{array}{l}\text { Selama masa Latihan Mengajar Terbimbing (LMT) } \\
\text { 8. Apakah guru pamong membantu anda dalam } \\
\text { mempersiapkan RPP? } \\
\text { 9. Apakah guru pamong membantu anda dalam } \\
\text { mempersiapkan media pembelajaran? } \\
\text { 10. Setelah anda mengajar, apakah ada tindak lanjut dari } \\
\text { guru pamong tentang media anda? } \\
\text { 11. Apakah guru pamong membantu anda selama proses } \\
\text { belajar mengajar di dalam kelas? } \\
\text { 12. Apakah guru pamong membantu anda dalam } \\
\text { merencanakan dan menjalankan PTK? } \\
\text { 13. Apakah guru pamong membantu anda dalam } \\
\text { melaksanakan kegiatan non-teaching? } \\
\text { 14. Apakah guru pamong menilai pembelajaran } \\
\text { terbimbing anda selama PL? } \\
\text { 15. Apakah guru pamong pernah berdiskusi dengan } \\
\text { dosen pembimbing anda? } \\
\text { 16. Apakah guru pamong pernah memberi sanksi } \\
\text { kepada anda ketika anda melanggar aturan sekolah? } \\
\text { 17. Apakah guru pamong pernah memberi sanksi } \\
\text { kepada anda ketika anda bersikap dan berprilaku } \\
\text { tidak baik? }\end{array}$ & V & V & V & V \\
\hline $\begin{array}{l}\text { Selama masa Latihan Mengajar Mandiri (LMM) } \\
\text { 18. Apakah guru pamong menilai pembelajaran mandiri } \\
\text { anda selama PL? } \\
\text { 19. Apakah guru pamong menilai anda dalam latihan } \\
\text { akhir pembelajaran? }\end{array}$ & & V & & \\
\hline
\end{tabular}

\section{Persepsi Mahasiswa PPLK terhadap} Tugas dan Tanggungjawab Guru Pamong selama Masa Observasi

Dari 7 (tujuh) pertanyaan yang diajukan dalam angket ini sehubungan dengan tugas dan tanggungjawab guru pamong selama masa observasi, tidak lebih dari setengah atau hanya 3 (tiga) pertanyaan yang mendapatkan persepsi positif dari mahasiswa PPLK. Dari persepsi tersebut mereka setuju bahwa guru pamong telah melakukan tugas dan tanggungjawabnya sehubungan dengan memberikan penjelasan tentang sikap dan prilaku mahasiswa PPLK seharusnya sebagai calon guru profesional, membimbing mereka untuk bersosialisasi dengan guru-guru lain, dan bersosialisasi dengan siswa-siswa di sekolah latihan, baik yang mereka ajar maupun yang tidak. Namun, 4 (empat) pertanyaan lainnya mendapatkan persepsi negatif dari mahasiswa PPLK. Menurut mereka guru pamong jarang membantu dan membimbing mereka merencanakan kegiatan non-mengajar, bersosialisasi dengan mahasiswa PPLK jurusan lain dan pegawai administrasi sekolah lainnya serta membantu mereka mengevaluasi kegiatan observasi mereka.

\section{Persepsi Mahasiswa PPLK terhadap} Tugas dan Tanggungjawab Guru Pamong selama Masa Latihan Mengajar Terbimbing (LMT)

Ada 10 pertanyaan yang diajukan di dalam angket sehubungan dengan tugas dan tanggungjawab guru pamong pada masa Latihan Mengajar Terbimbing. Menurut data yang terkumpul dari persepsi mahasiswa PPLK, diketahui bahwa guru 
pamong jarang memberikan bantuan dan membimbing mereka dalam mempersiapkan media ajar, membimbing selama proses mengajar, melakukan tugas/kegiatan non-mengajar serta melakukan diskusi dengan dosen pembimbing mahasiswa PPLK itu sendiri.

Sebagaimana tercantum dalam Buku Pedoman PPLK (2010) bahwa guru pamong harus membantu siswa PPLK dalam membuat dan mengembangkan media ajar. Mereka seharusnya juga memberikan pendapat tentang relevansi media ajar dengan RPP. Selama mahasiswa PPLK melakukan proses pengajaran, adalah tugas guru pamong untuk selalu mendampingi. Mereka seharusnya "secara terus-menerus mengevaluasi dan memonitor lingkungan pembelajaran, membuat perubahan dan penyesuaian seperlunya, bahkan membuat perubahan besar terhadap pengharapan awal..." (Schon in Goodwyn, 1997). Dari persepsi mahasiswa PPLK tersebut secara umum guru pamong belum melaksanakan tugas dan tanggungjawab mereka sesuai dengan aturan yang telah diterapkan dan sesuai dengan idealnya guru pamong.

\section{Persepsi Mahasiswa PPLK terhadap Tugas dan Tanggungjawab Guru Pamong selama Masa Latihan Mengajar Mandiri (LMM)}

Ada 2 (dua) pertanyaan di angket sehubungan dengan indikator ketiga. Kedua pertanyaan tersebut mendapatkan respon yang positif dari responden. Mereka menyatakan bahwa guru pamong melaksanakan tugas dan tanggungjawab mereka dalam mengevaluasi mahasiswa PPLK dengan menggunakan on-going assessment dan ujian akhir.

Guru pamong melakukan penilaian terhadap mahasiswa PPLK dan mereka bahkan menyediakan waktu berdiskusi untuk membahas proses pengajaran yang telah dilakukan mahasiswa PPLK tersebut di dalam kelas.

\section{SIMPULAN DAN SARAN}

Dari hasil penelitian tersebut dapat disimpulkan bahwa dari ketiga periode pelaksanaan PPLK oleh mahasiswa Jurusan Bahasa dan Sastra Inggris, hanya pada satu periode saja guru pamong melaksanakan tugas dan tanggungjawab mereka sebagaimana mestinya. Yaitu pada periode Latihan Mengajar Mandiri (LMM). Pada dua periode lainnya, Observasi dan Latihan Mengajar Terbimbing (LMT) secara umum atau lebih dari setengah responden mengatakan bahwa guru pamong tidak melaksanakan tugas dan tanggungjawab mereka seperti tertuang dalam buku pedoman pelaksanaan PPLK.

Berdasarkan simpulan tersebut, maka guru pamong hendaklah lebih memperhatikan tugas dan tanggungjawab mereka dalam membantu mahasiswa PPLK sehingga tujuan PPLK dapat dicapai dengan baik. Mereka seharusnya memberikan bantuan dan bimbingan sebagaimana mestinya khususnya pada Latihan Mengajar Terbimbing (LMT). UPPL sebagai unit pelaksana dari universitas seharusnya mengkaji kembali pelaksanaan PPLK. UPPL juga sebaiknya mengadakan coaching baik dengan guru pamong maupun dengan mahasiswa PPLK sehingga kedua belah pihak mengetahui tugas dan tanggungjawab mereka selama pelaksanaan PPLK. Seiring dengan pemenuhan tanggungjawab guru pamong, mahasiswa PPLK juga harus aktif mendiskusikan semua kegiatan pengajaran mereka dengan guru pamong dalam usaha meningkatkan kemampuan mengajar mereka.

\section{DAFTAR PUSTAKA}

Alwasilah, A. C. 2006. Pokoknya kualitatif:Dasar-dasar merancang dan melakukan penelitian kualitatif. Cetakan ke-3. Jakarta: Pustaka Jaya.

Anonim. 2009. Pedoman pelaksanaan program pengalaman lapangan kependidikan mahasiswa. Padang: Unit Program Pengalaman Lapangan UNP. 
Azwar, S. 2008. Penyusunan skala psikologi. Yogyakarta: Pustaka Pelajar.

Brandon University. 2009. Role of the Cooperating Teacher. Retrieved from http://www2.brandonu.ca/academic/ed ucation/field/20.html on December 28, 2009.

Gay, L.R, Geoffrey, E. M. \& Airasian, P. 2009. Educational research: Competencies for analysis and applications. New Jersey: Pearson.

Goodwyn, A. 1997. Developing English teachers. Buckingham: Open University Press.

Lewis, M. 2002. Classroom management. In J.C. Richards and W.A. Renandya Methodology in language teaching: An anthology of current practice (Eds.) pp. 40-48. Cambridge: Cambridge University Press.

Mulyasa, E. 2005. Kurikulum tingkat satuan pendidikan: Suatu panduan praktis. Bandung: PT. Remaja Rosdakarya Offset Bandung.

Sanjaya, W. 2006. Strategi pembelajaran berorientasi standar proses pendidikan. Jakarta: Kencana (Prenada Media Group).

Sanjaya, W. 2005. Pembelajaran dalam implementasi kurikulum berbasis kompetensi. Jakarta Kencana (Prenada Media Group). 